\title{
Group Activity as the Psychological Factor of the Developing of Learners' Creativity
}

\section{Групова діяльність як психологічний чинник розвитку креативності студентів}

\section{Nataliia Antiukhova}

Ph.D. in Psychology, Assistant Professor of the Department of German Philology and Translation, the Institute of Philology, Taras Shevchenko National University of Kyiv, Kyiv (Ukraine)

ORCID ID: https://orcid.org/0000-0003-4550-6702

Researcher ID: http://www.researcherid.com/rid/AAQ-4278-2021

E-mail: a-natalya@ukr.nee

\section{Наталія Антюхова}

Кандидат психологічних наук, доцент кафедри германської філології та перекладу, Інститут філології Київського національного університету імені Тараса Шевченка, м. Київ (Україна)

\section{Liana Onufriieva}

Dr. in Psychology, Professor, Head of the Department of General and Applied Psychology, Kamianets-Podilskyi National Ivan Ohiienko University, Kamianets-Podilskyi (Ukraine)

ORCID ID: https://orcid.org/0000-0003-2442-4601

Researcher ID: http://www.researcherid.com/rid/R-5598-2018

Scopus Author ID: 57214601047

E-mail: kpnu_lab_ps@ukr.net

\section{Ліана Онуфрієва}

Доктор психологічних наук, професор, завідувач кафедри загальної та практичної психології, Кам'янець-Подільський на-

Address for correspondence, e-mail: kpnu_lab_ps@ukr.net Copyright: (C) Antiukhova Nataliia, Onufriieva Liana

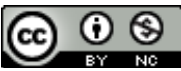

The article is licensed under CC BY-NC 4.0 International (https://creativecommons.org/licenses/by-nc/4.0/)

(C) Antiukhova Nataliia, Onufriieva Liana DOI (article): https://doi.org/10.32626/2227-6246.2021-53.11-34 
DOI: https://doi.org/10.32626/2227-6246.2021-53

2021. випуск 53

ціональний університет імені Івана Огієнка, м. Кам'янець-Подільський (Україна)

The contribution of the author: Antiukhova N. $-50 \%$, Onufriieva L. $-50 \%$. Авторський внесок: Антюхова Н. - 50\%, Онуфрієва Л. - 50\%.

\section{ABSTRACT}

The aim of research is: to investigate the level of the development of creative potential of students - future foreign language teachers, to apply the program of group activity developed by us in order to develop the creativity of respondents, to analyze its effectiveness.

The following theoretical methods of the research were used to solve the tasks formulated in the article: a categorical method, structural and functional methods, the methods of the analysis, systematization, modeling, generalization. Also we used experimental methods, such as statement research. For the last one we used such methodology, as: The Methodology "Motivation of the professional activity" by K. Zamfir in the modification of A. Rean, "The Methodology of determining the orientation of the individual» (by V. Smekalo and $M$. Kucher). Also we used the ranking technique, the main task of which was to identify the most important criteria of pedagogical skills, which, according to respondents, will mostly influence the formation of creative potential.

The results of the research. Thus, the analysis of our results has shown that the creative potential of the person is manifested and acquired in the process of such activities, which gives this activity a problem-creative, exploratory nature. Our own experience of creative activity should be the basic element, given of which may be the formation of other elements (knowledge, skills, human attitude to the world, etc.). In this case, the education and upbringing of students from the early beginning will have the aim of the development of their personality, and, consequently, the development of students' creative potential.

The results having been obtained by us allow us to use the psychological mechanisms of the development of creative personal traits (the activity, reflexive mechanisms of the person, the formation of self-estimation, self-regulation) in the process of professional training of students at higher educational institutions. Thus, in the basis of empirical and theoretical (semantic) abstraction and generalization there are mental actions that are controlled by reflexive mechanisms. The learner in the process of his/her activity takes the position of a re(c) Antiukhova Nataliia, Onufriieva Liana

DOI (article): https://doi.org/10.32626/2227-6246.2021-53.11-34 
searcher, a creator, who is capable of reflexive analysis of his/her own actions. In such a way the procedure of reflection is closely related to self-esteem and self-regulation, these processes in the course of learning, according to the theory of group learning, which are also given considerable importance.

Conclusions. It was proved, that the developmental nature of group learning largely depends on the means and methods of obtaining theoretical knowledge by individuals. The content of developmental group learning is didactically built on the logic of theoretical thinking (the leading role belongs to the theoretical semantic generalization, deduction, semantic reflection, etc.).

The procedural characteristics of the theory of developmental group learning include:

- the concept of purposeful educational activity, which differs from those positions that it has the aim at obtaining by the subjects of learning not only knowledge, skills and abilities, but also to achieve a theoretical level of thinking of the individual. These characteristics are: the presence of the learner, internal cognitive motives derived from cognitive needs; the presence of a clear goal of conscious self-change, understanding and acceptance by individuals of all information without the choice of educational tasks; the occupation by the learner of the position of a full-fledged subject of the activity, which is capable of independent implementation of all stages of this activity: goal formulation, activity planning, goal realization and the analysis (the evaluation of the results of the activity); active mastering of theoretical knowledge, skills, ways of carrying out mental actions, purposeful planning and providing actions, mastering of the general principles of the decision of problems and solving creative tasks (the student takes a position of the researcher-creator); the reflexive nature of the analysis of the person's own actions, the experience of creative reflection, which are the basic elements in the formation and the development of the personal traits;

- the problematization of the activity - the problematic explanation by the teacher the educational material, which causes for students a remarkable creative effort to present their own opinions creatively, to formulate conclusions, hypotheses and test them in constructive dialogues with opponents;

- the use of the method of educational tasks, which consists of the fact that the solution of the problem is not in finding a certain conclusion, but in finding general methods of actions, the principles of solving similar problems by a whole class.

(C) Antiukhova Nataliia, Onufriieva Liana DOI (article): https://doi.org/10.32626/2227-6246.2021-53.11-34 
DOI: https://doi.org/10.32626/2227-6246.2021-53

2021. випуск 53

Key words: group activity, the developing of learners' creativity, students' creative potential, constructive dialogues with opponents, to formulate conclusions, hypotheses.

\section{Introduction}

Group activity is considered to be one of the important factors to improve learners' communication. Different scientists (Гончарук \& Онуфрієва, 2018; Mykhalchuk \& Kryshevych, 2019) have developed many approaches according to group activity over the last time. Group activity is defined by us as the process of teaching language in class, as a co-operative form of the activity, during which students share their aims and responsibilities to complete a task having been assigned by the teacher in groups or in pair (Онуфрієва, 2020).

According to N. Khupavtseva (2020), group activity is a generic term covering a multiplicity of techniques in which two or more students solved a task that involved collaboration and self-initiated language. We define group activity as a form of learning activity which involves a small group of learners working together. The group may do a single task or some different parts of a larger task. In addition, each group is understood by us as a group of people which includes at least three and ordinarily fewer than twenty individuals who are interdependent, influence one another over some period of time, share a common goal or a purpose, play some specialized role, have a sense of mutual belonging, maintain norms and standards for group membership and who are engaged into the process of interactive communication (Onufriieva, 2017). From the point of view of these definitions we can conclude that group activity is some kind of learning activity which involves learners working together in a small team or group to perform a task with the objective which gives more opportunities for students to use or to practice the language.

Group activity, to our mind, can be classified into three general types: the activity within informal learning group, in (C) Antiukhova Nataliia, Onufriieva Liana

DOI (article): https://doi.org/10.32626/2227-6246.2021-53.11-34 
the structure of formal learning group, and study by teams or in collective (cooperative) based groups. The first type of group activity within informal learning groups are clustering students into a single class session, for example, asking the students to turn to their neighbor and to spend two minutes for discussing a question asked to this student. The informal learning group can be used to focus students' attention on the materials to be learned, set a positive mood in learning, help to set expectations as to be covered in a class process, ensure students to participate in cognitive process and rehearse the material having been taught, to summarize what was learned by the students. Also before introducing the next task, the teacher provides closure to the instructional session.

The second type of group is formal learning group. In this type of group activity the teams are formed to complete a specific task, such as performing a lab experiment, writing a report, carrying out a project or prepare a paper for presentation. The latter type of group activity is to teach teams to participate in cooperative based groups which are long-term groups with stable memberships whose primary responsibility is to provide students with the support, the encouragement and assistance in completing course requirements and assignments. In addition, such teams inform their members about lectures and assignments when someone has missed some lesson or a session.

Learning in the context of sharing, responding and communicating with other students is a major teaching strategy in teaching context. Students who work individually often do not reach a progress significantly. Conversely, students who are working in groups often can solve complex problems with minimal assistance. The experience of working together not only helps students to learn the material, it is also consistent with a real world.

In group activities pupils learn to listen to different ideas, learn to discuss and to negotiate. They often take part in all

(c) Antiukhova Nataliia, Onufriieva Liana DOI (article): https://doi.org/10.32626/2227-6246.2021-53.11-34 
DOI: https://doi.org/10.32626/2227-6246.2021-53

2021. випуск 53

forms of the activity and sometimes they feel comfortable to participate in the experiment and to speak the language. Every member of group activity has more opportunities for being independent and they can have some learning decisions. In language teaching group activity provides great opportunities to practice new words, conversations, sentence constructions and functional elements of communication, such as making a particular type of telephone call or initiating a conversation.

In our researches we have shown that group activity can give better learning achievements in English language teaching and studying. We mentioned the lockstep approach which gives very little opportunity for each teacher to talk and to receive input for acquisition. For example, among of 30 students each of them would only have one chance to speak for $1 / 3$ of period of time, in comparison with a group of 4 students in which each person has the opportunity to speak for $\mathrm{j}$ of the period. This is due to some types of group activity, such as the discussion, the dispute. Among the advantages of the discussion, N. Mykhalchuk and L. Onufriieva (Mykhalchuk \& Onufriieva, 2020) mention some main advantages of this group activity. They are the following:

1. Group activity generates interactive language in lockstep traditional classroom, teacher's talk is more dominant. Teachers give students explicit explanation of Grammar, propose some drills for students, and lead a whole class discussion. By doing these tasks, the students get less opportunity to practice the language. They tend to be passive. Only a few students have got a chance to practice the language and consequently the English lesson becomes very boring. Small micro-groups are provided more opportunities for students' initiation, for face-to-face discussions, for taking part in practice in negotiation of meaning, for extended conversational exchanges, and for students' adoption of roles that would otherwise be impossible. This is the content we mention that has to be gene(c) Antiukhova Nataliia, Onufriieva Liana

DOI (article): https://doi.org/10.32626/2227-6246.2021-53.11-34 
rated more negotiation of meaning than teacher-fronted activities in a paradigm of micro-group activities.

2. Group activity offers an embracing affective positive climate about which we'll mention when students have group activities. In such ways they feel themselves more secured. Students can not easily be criticized or insulted. Inhibited students become active and vocal in the process of learning and teaching. In small micro-groups pupils work together to achieve a certain goal. By working in groups, students' motivation and self-confidence are increased.

3. Group activity promotes each learner great responsibility and autonomy. Compared to the whole-class activity in which students tend to be passive and only some individuals relax so much and hide themselves in the class, group activity makes students to be more responsible for doing actions and making progress. In small micro-groups, it is difficult for students to keep quiet and hide themselves. Therefore, all students get the equal chance to experiment with the language having been learned.

4. Group activity is a step toward individualizing instructions. Micro-group can help students with mixed abilities to accomplish different goals. It makes the teacher easy to recognize the individual difference in terms of age, cultural heritage, field of study, cognitive style, motivation, aptitude and personality. In addition to the above advantages, scientists (Івашкевич \& Гудима, 2020) mention that group activity provides a "naturalistic environment». This means that students in group activity are free from anxiety to experiment with the target language. This is like when they are exposed to a certain linguistic environment in which they can pick up the language. Further, group activity minimizes the occurrence of those unpleasant situations and maximizes the process of learning and having got satisfaction from those results as working together. We also touch some advantages of group activity in cooperative learning.

(C) Antiukhova Nataliia, Onufriieva Liana DOI (article): https://doi.org/10.32626/2227-6246.2021-53.11-34 
DOI: https://doi.org/10.32626/2227-6246.2021-53

2021. випуск 53

In addition to the advantages mentioned above, we further mention five weak sides of the application of group activity in the classroom. These are the problem of controlling students, the use of mother tongue during the activities, the reinforcement of students' conflicts and mistakes in the classroom, the difficulties with monitoring of all activities in each group. The last problem is related to the students' cognitive styles: some learners may prefer to do activities alone.

So, group activity is a technique by which students can work or learn together to do different tasks in small teams consisting of four or five students with different abilities. There are some reasons for group activity to be superior: generating interactive language, offering embracing affective climate, promoting learners' responsibilities, being autonomous, to do different steps toward individualizing instructions. On the other hand, group activity may also have problems such as no longer to control the whole class, the use of students' native language, the reinforcement of students' mistakes, and the difficulty to monitor all groups. All these problems can be overcome by teachers if we want to develop students' creativity.

The purpose of our experiment was to investigate the level of the development of creative potential of students - future foreign language teachers, to apply the program of group activity developed by us in order to develop the creativity of respondents, to analyze its effectiveness.

\section{Methods of the research}

The following theoretical methods of the research were used to solve the tasks formulated in the article: a categorical method, structural and functional methods, the methods of the analysis, systematization, modeling, generalization. Also we used experimental methods, such as statement research. For the last one we used such methodology, as: The Methodology (c) Antiukhova Nataliia, Onufriieva Liana

DOI (article): https://doi.org/10.32626/2227-6246.2021-53.11-34 
DOI: https://doi.org/10.32626/2227-6246.2021-53

2021. випуск 53

"Motivation of the professional activity» by K. Zamfir in the modification of A. Rean (Замфир, 2021), «The Methodology of determining the orientation of the individual» (by V. Smekalo and M. Kucher) (1988). Also we used the ranking technique, the main task of which was to identify the most important criteria of pedagogical skills, which, according to respondents, will mostly influence the formation of creative potential.

In order to obtain more valid results of our research from the general sample (which includes 1250 respondents) by the method of randomization, experimental and control groups were formed, which included 194 of students:

- experimental groups:

E1 - 47 first-year students of Kamianets-Podilskyi National Ivan Ohiienko University;

E2 - 54 second-year students of the Institute of Philology, Taras Shevchenko National University of Kyiv;

- control groups:

C1 - 45 first-year students of the Institute of Philology, Taras Shevchenko National University Kyiv;

C2 - 48 second-year students of Kamianets-Podilskyi National Ivan Ohiienko University.

The experiment lasted from September, 2020 to April, 2021.

\section{Results and their discussion}

In order to identify the level of the development of the motivational component of students' creativity, the following techniques were used:

The Methodology "Motivation of the professional activity" by K. Zamfir in the modification of A. Rean (Замфир, 2021). The purpose of using this technique is to identify creative motivation of students in their professional activities. The methodology is based on the concept of internal and external motivation. Respondents are offered a list of motives for

(c) Antiukhova Nataliia, Onufriieva Liana DOI (article): https://doi.org/10.32626/2227-6246.2021-53.11-34 
DOI: https://doi.org/10.32626/2227-6246.2021-53

2021. випуск 53

professional activity and they were instructed to assess their significance for themselves on a five-point scale. Our research uses indicators of intrinsic motivation, which are a source of creative motivation.

"The Methodology of determining the orientation of the individual» (by V. Smekalo and M. Kucher) (1988). This technique is used to determine the creative orientation of the specialist. The text of the methodology contains 27 statements and three answers to each of them. The respondents have to choose one of the proposed answers to each statement.

"The Methodology of determining the orientation of the individual» (by V. Smekalo and M. Kucher) (1988) identifies the following types of orientation: self-orientation, focus on the case (on the profession), focus on solving the problem. We believe that creative orientation can be diagnosed as business orientation, because the manifestation of creative personal traits takes a place in the process of professional activity. Then, according to the key of «The Methodology of determining the orientation of the individual» (by V. Smekalo and M. Kucher) (1988), the level of creative orientation of the student was determined.

After organizing our experimental activity, the data on the motivational component (see Table 1) indicate that students of both experimental and control groups have an insufficient level of the development of creative motivation, although the results of creative orientation of respondents were enough high (data on the creative focus on mastering both the profession and the communication).

These results suggest that students have a great desire to acquire the knowledge, skills and the abilities individuals need in future professional activities, which will positively affect their participation in the experimental program, the desire to develop their own creative potential (see Table 2). 
Average values of indicators «creative motivation" and "creative orientation of the person" of students of experimental and control groups

(in points, statement research)

\begin{tabular}{|c|c|c|c|}
\hline Groups & $\begin{array}{c}\text { Creative } \\
\text { motivation }\end{array}$ & $\begin{array}{c}\text { The value ot } \\
\text { t-Student criterion }\end{array}$ & $\begin{array}{c}\text { Level } \\
\text { significance, } \mathbf{P}\end{array}$ \\
\hline E1 & $17.3 \pm 1.2$ & 0.83 & 0.05 \\
\hline E2 & $18.4 \pm 2.4$ & 0.57 & 0.05 \\
\hline C1 & $15.3 \pm 0.06$ & 0.48 & 0.01 \\
\hline C2 & $17.8 \pm 1.8$ & 0.63 & 0.05 \\
\hline Groups & $\begin{array}{c}\text { Creative } \\
\text { orientation }\end{array}$ & $\begin{array}{c}\text { The value ot } \\
\text { t-Student criterion }\end{array}$ & $\begin{array}{c}\text { Level } \\
\text { significance, } \mathbf{P}\end{array}$ \\
\hline E1 & $26.3 \pm 1.7$ & 0.44 & 0.01 \\
\hline E2 & $28.9 \pm 2.3$ & 0.53 & 0.05 \\
\hline C1 & $27.1 \pm 1.8$ & 0.49 & 0.01 \\
\hline C2 & $29.4 \pm 1.9$ & 0.57 & 0.05 \\
\hline
\end{tabular}

Table 2

The distribution of students of experimental and control groups by the indicator "creative orientation of the person" (in $\%$, statement research)

\begin{tabular}{|c|c|c|c|}
\hline \multirow{2}{*}{ Groups } & \multicolumn{3}{|c|}{ Creative orientation of the person } \\
\cline { 2 - 4 } & $\begin{array}{c}\text { Orientation } \\
\text { on myself }\end{array}$ & $\begin{array}{c}\text { Orientation on } \\
\text { communication }\end{array}$ & $\begin{array}{c}\text { Orientation on mastering } \\
\text { the profession }\end{array}$ \\
\hline E1 & 15.3 & 37.8 & 46.9 \\
\hline E2 & 12.4 & 32.9 & 54.7 \\
\hline C1 & 17.3 & 30.8 & 51.9 \\
\hline C2 & 16.2 & 38.4 & 45.4 \\
\hline
\end{tabular}

In order to describe in more details the indicator «creative orientation of the individual to master the future profession"

(c) Antiukhova Nataliia, Onufriieva Liana DOI (article): https://doi.org/10.32626/2227-6246.2021-53.11-34 
DOI: https://doi.org/10.32626/2227-6246.2021-53

2021. випуск 53

we used the ranking technique, the main task of which was to identify the most important criteria of pedagogical skills, which, according to respondents, will mostly influence the formation of creative potential.

The following criteria were selected as the most significant ones:

1. Knowledge of the subject.

2. Authority of the teacher.

3. The abilities to teach material.

4. Love for this subject.

5. The ability to establish discipline in the classroom.

6. A high level of preparation for pedagogical activity.

7. The ability to conduct psychological and pedagogical diagnosis independently, without the help of a school psychologist.

8. Erudition, general culture.

9. The implementation of education in the learning process.

10. A contact with the audience, the culture of communication.

11. The ability to optimize the learning process.

12. To improve the pedagogical skills. dents.

13. The ability to organize individual activity with stu-

14. High intellectual development of the teacher.

15. A contact with colleagues.

16. The ability to activate students.

We've justified the choice of this task by the fact that pedagogical mastery is the highest level of education and training, which is constantly improving and is available to every teacher who works by vocation and loves children. The creativity is an integral, the most important component of pedagogical skills, because through creative activity in pedagogical process it is possible to reach the highest heights, such as the possibility to provide innovative activity. Pedagogical mastery is a process (c) Antiukhova Nataliia, Onufriieva Liana

DOI (article): https://doi.org/10.32626/2227-6246.2021-53.11-34 
of self-development and self-improvement, a way to achieve the level of acme. It is known that the driving force of the person's development is contradictions, cognitive dissonance and their overcoming. In the professional activity of each teacher the main contradiction that ensures the development of students is the contradiction between the abilities, giftedness of a man and the requirements of pedagogical activity, rules of conducting the pedagogical process and so on. The development is not only initiated by the requirements of the activity, but also it is regulated by both quantitatively and qualitatively. The personal development is carried out by providing a certain quality characteristics of efficiency, adaptation to the requirements and conditions of creative activity. Contradictions between goals, objectives and the means are available to achieve them, between aspirations and opportunities to meet them, between tendencies to variability and to stereotyping. All these characteristics are solved by human activity. The abilities are known to develop only in the process of students' activity. Creative abilities are developed in the activities that require a creative approach to its implementation. Since creativity is organically inherent in the pedagogical activity, the creative abilities of the teacher should be considered not so much as special talents, but as a high level and harmonious combination of all pedagogical skills. This is a level of mastery at which the abilities acquire a new quality, they are expressed in a creative, original, non-standard style of the person's activity. The latter is characterized, first of all, by independent formulation of problems, the so-called intellectual initiative, an original way of solving tasks, the desire and the ability to see something new in the ordinary things.

So, according to the results of our experiment, we proposed some tendencies how to make group activity productive. Group activity gives students more opportunities to speak and practice what they've learnt. It also helps students to build their interpersonal, social and emotional skills. Group, pair 
DOI: https://doi.org/10.32626/2227-6246.2021-53

2021. випУСК 53

and project activity can be used during lessons on different topics and help to develop autonomy in the classroom, students' confidence and understanding of their own weaknesses. It helps them to improve language skills (especially speaking and listening comprehension) and also collaboration skills. But often group activity becomes too complicate, takes a lot of time and doesn't bring good results. To get the most positive characteristic of group activity we need to know what problems students face during their group and pair activity and find out what we need to change in our teaching in order to improve the effectiveness of group activity.

To get the better understanding of students' opinions about group activity and the problems they face during their lesson we asked students to complete a questionnaire about their own experience in participating in group activity. In this questionnaire each student was treated anonymously. There is the questionnaire with students' answers below (Table 3).

Table 3

A Questionnaire for students about their preferences of group activity (in \%)

\begin{tabular}{|l|c|c|c|}
\hline \multicolumn{1}{|c|}{ Questions for students } & Yes & $\begin{array}{c}\text { Not } \\
\text { sure }\end{array}$ & No \\
\hline $\begin{array}{l}\text { 1. Do you like group and pair forms of the } \\
\text { activity? }\end{array}$ & 56.1 & 22.4 & 21.5 \\
\hline $\begin{array}{l}\text { 2. Do you thing group activity is useful for } \\
\text { your learning? }\end{array}$ & 56.9 & 20.0 & 23.1 \\
\hline 3. Is group activity difficult for you? & 65.1 & 20.0 & 14.9 \\
\hline $\begin{array}{l}\text { 4. Do all students equally participate in group } \\
\text { activities? }\end{array}$ & 35.8 & 30.8 & 33.4 \\
\hline 5. Do you like working with your partner? & 71.2 & 18.3 & 10.5 \\
\hline 6. Why do you like/don't like group activity? & The open question \\
\hline 7. What is the best thing about group activity? & The open question \\
\hline $\begin{array}{l}\text { 8. What is the worst thing about the group } \\
\text { activity? }\end{array}$ & The open question \\
\hline
\end{tabular}

C Antiukhova Nataliia, Onufriieva Liana

DOI (article): https://doi.org/10.32626/2227-6246.2021-53.11-34 
The students' answers showed that not all of students like group activity and the most of them consider group activity as useless one. A half of students said that group activity is difficult for them and almost each student answered that not all students equally participated in group activity. The fifth question has the same amount of «yes», «not sure» and «no» answers.

Some of the reasons why students like group activity and the best things about it, that students have mentioned, were:

- It's fun.

- I can ask my friends for help.

- It gives me a great opportunity to show my skills.

- I can talk a lot.

Reasons why students don't like group activity and the worst things having been mentioned about it were:

- My partners don't do anything for my studying.

- I often don't understand the task.

- Not enough time to complete the task.

- Tasks are useless.

In order to get the full answer to our first question we also paid a lot of attention observing students' performance themselves during group tasks.

In the process of this observation we noticed that group activity really has problems on every stage. First of all, students sometimes have problems with understanding and remembering of the task. Also they can't often identify the most important parts of the task and decide how to divide solving of tasks between themselves.

Another problem we noticed was that unmotivated students refused to do the activity and expected their partners to do it in the whole or just do the simplest parts of the task.

Comparing the results of different kinds of group activity we noticed that when students know exactly what they expected to learn and what results they needed to reach they worked much more willingly and therefore effectively. It helped me 
DOI: https://doi.org/10.32626/2227-6246.2021-53

2021. випуск 53

to realize that one of the main aspects of group activity was students' motivation.

So, according to the results of this questionnaire and our own observation we identified four main problems:

1. Some of students do all the activities during solving group tasks, because their partners refuse to do the activity or do it poorly. These students would like to change their partners.

2. Students often don't understand the task correctly. After receiving the task they continue asking the teacher and each other what they are supposed to do.

3. Sometimes students don't do the activity because «there is no use to do it» as long as there is no visible results and so the activity can't be checked up properly.

4. Students can't see the results of tasks and therefore consider them as useless for their learning.

Thus, the analysis of our results has shown that the creative potential of the person is manifested and acquired in the process of such activities, which gives this activity a problem-creative, exploratory nature. Our own experience of creative activity should be a basic element, given of which may be the formation of other elements (knowledge, skills, human attitude to the world, etc.). In this case, the education and upbringing of students from the early beginning will have the aim of the development of their personality, and, consequently, the development of students' creative potential.

The results having been obtained by us allows us to use in the process of professional training of students at higher educational institutions the psychological mechanisms of the development of creative personal traits (the activity, reflexive mechanisms of the person, the formation of self-estimation, self-regulation). Thus, in the basis of empirical and theoretical (semantic) abstraction and generalization there are mental actions that are controlled by reflexive mechanisms. The learner in the process of his/her activity takes the position of a researcher, a creator, who is capable of reflexive analysis (c) Antiukhova Nataliia, Onufriieva Liana

DOI (article): https://doi.org/10.32626/2227-6246.2021-53.11-34 
of his/her own actions. In such a way the procedure of reflection is closely related to self-esteem and self-regulation, these processes in the course of learning, according to the theory of group learning, which are also given considerable importance.

\section{Conclusions}

It was proved, that the developmental nature of group learning largely depends on the means and methods of obtaining theoretical knowledge by individuals. The content of developmental group learning is didactically built on the logic of theoretical thinking (the leading role belongs to the theoretical semantic generalization, deduction, semantic reflection, etc.).

The procedural characteristics of the theory of developmental group learning include:

- the concept of purposeful educational activity, which differs from those positions that it has the aim at obtaining by the subjects of learning not only knowledge, skills and abilities, but also to achieve a theoretical level of thinking of the individual. These characteristics are: the presence of the learner, internal cognitive motives derived from cognitive needs; the presence of a clear goal of conscious self-change, understanding and acceptance by individuals of all information without the choice of educational tasks; the occupation by the learner of the position of a full-fledged subject of the activity, which is capable of independent implementation of all stages of this activity: goal formulation, activity planning, goal realization and the analysis (the evaluation of the results of the activity); active mastering of theoretical knowledge, skills, ways of carrying out mental actions, purposeful planning and providing actions, mastering of the general principles of the decision of problems and solving creative tasks (the student takes a position of the researcher-creator); the reflexive nature of the analysis of the person's own actions, the experience of creative reflection, which are the basic elements in the formation and the development of the personal traits;

(C) Antiukhova Nataliia, Onufriieva Liana DOI (article): https://doi.org/10.32626/2227-6246.2021-53.11-34 
DOI: https://doi.org/10.32626/2227-6246.2021-53

2021. випуск 53

- the problematization of the activity - the problematic explanation of the educational material by the teacher, which causes a remarkable creative effort for students to present their own opinions creatively, to formulate conclusions, hypotheses and test them in constructive dialogues with opponents;

- the use of the method of educational tasks, which consists of the fact that the solution of the problem is not in finding a certain conclusion, but in finding general methods of actions, the principles of solving similar problems by a whole class.

\section{Literature}

Гончарук Н., Онуфрієва Л. Психологічний аналіз рівнів побудови комунікативних дій. Психолінгвістика. Психолингвистика. Psycholinguistics, 2018, 24 (1), 97-117. URL : https://doi.org/10.31470/ 2309-1797-2018-24-1-97-117.

Замфир К. Методика «Мотивация профессиональной деятельности». В модификации А. Реана. 2021. URL : http://www.vashpsixolog. ru/psychodiagnostic-school-psychologist/122-tests-guidance/716motivation-professional-activity-c-zamfir-technique-to-modify-aa-reana.

Івашкевич E., Гудима О. Psychological ways of the development of intercultural competence of pupils in the field of «Foreign Language Education» (according to the experience of education in foreign countries). Збірник наукових пращь «Проблеми сучасної психоло2ï», 2020, 49, 84-105. URL : https://doi.org/10.32626/2227-6246. 2020-49.84-105.

Михальчук Н., Онуфрієва Л. Psychological principles of learner's autoпоту. Збірник наукових праць «Проблели сучасної психологї», 2020, 49, 244-268. URL : https://doi.org/10.32626/2227-6246. 2020-49.244-268.

Онуфрієва Л.А. Розвиток професіоналізму майбутніх фахівців соціономічних професій: соціально-психологічний вимір: монографія. Київ : Видавець Бихун В.Ю., 2020. 320 с. ISBN 978-617-7699-08-7.

Тест В. Смекала и М. Кучера (направленность личности). Науч. ред. Н.M. Пейсахов. Казань : Издательство Казанского университета, 1988. 296 c.

(C) Antiukhova Nataliia, Onufriieva Liana

DOI (article): https://doi.org/10.32626/2227-6246.2021-53.11-34 
DOI: https://doi.org/10.32626/2227-6246.2021-53

2021. випУСК 53

Хупавцева Н. Вплив особистісних чинників на процес фасилітативної взаємодії. Збірник наукових праць "Проблеми сучасної психологї̈», 2020, 49, 363-385. URL : https://doi.org/10.32626/22276246.2020-49.363-385.

Mykhalchuk, Nataliia, \& Kryshevych, Olga. The peculiarities of the perception and understanding of Sonnets written by W. Shakespeare by the students of the Faculty of Foreign Languages. Psycholinguistics. Психолінгвістика. Психолингвистика, 2019, 26 (1), 265-285. URL : https://doi.org/10.31470/2309-1797-2019-26-1-265-285.

Onufriieva, L.A. The Psychology of Professional Realization of a Future Specialist's Personality: Theoretical and Methodological Aspect. Monograph. Rzeszów : BonusLiber, 2017. 194 s. ISBN 978-83-6544183-6.

\section{References}

Honcharuck, Nataliia, \& Onufriieva, Liana. (2018). Psykholohichnyi analiz rivniv pobudovy komunikatyvnykh dii [Psychological analysis of levels of communicative actions' constructing]. Psykholinhvistyka. Psikholingvistika. Psycholinguistics - Psycholinguistics. Psycholinguistics. Psycholinguistics, 24 (1), 97-117. Retrieved from https:// doi.org/10.31470/2309-1797-2018-24-1-97-117 [in Ukrainian].

Zamfir, K. (2021). Metodika «Motivatsiia professionalnoi deiatelnosti». $V$ modifikatsii A. Reana [The Methodology "Motivation of the professional activity" ]. In the modification of A. Rean. Retrieved from http://www.vashpsixolog.ru/psychodiagnostic-school-psychologist/ 122-tests-guidance/716-motivation-professional-activity-c-zamfirtechnique-to-modify-a-a-reana [in Russian].

Ivashkevych, E., \& Hudyma, A. (2019). Psychological ways of the development of intercultural competence of pupils in the field of «Foreign Language Education" (according to the experience of education in foreign countries). Zbirnyk naukovykh prats "Problemy suchasnoi psykholohii» - Collection of research papers "Problems of modern Psychology», 49, 84-105. Retrieved from https://doi.org/10.32626/ 2227-6246.2020-49.84-105.

Mykhalchuk, N., \& Onufriieva, L. (2020). Psychological principles of learner's autonomy. Zbirnyk naukovykh prats «Problemy suchasnoi psykholohii»-Collection of research papers «Problems of modern Psychology», 49, 244-268. Retrieved from https://doi.org/10.32626/22276246.2020-49.244-268.

Onufriieva, L.A. (2020). Rozvytok profesionalizmu maibutnikh fakhivtsiv sotsionomichnykh profesii: sotsialno-psykholohichnyi vymir [The deve-

(c) Antiukhova Nataliia, Onufriieva Liana

DOI (article): https://doi.org/10.32626/2227-6246.2021-53.11-34 
DOI: https://doi.org/10.32626/2227-6246.2021-53

2021. випуск 53

lopment of the professionalism of future specialists of socionomic professions: socio-psychological aspect]. Kyiv : Publisher Bykhun V.Yu. ISBN 978-617-7699-08-7 [in Ukrainian].

Test V. Smekala i M. Kuchera (napravlennost lichnosti) [ "The Methodology of determining the orientation of the individual» (by V. Smekalo and M. Kucher)] (1988). N.M. Peisakhov (Ed.). Kazan : Publishing House of Kazan University [in Russian].

Khupavtseva, N. (2020). Vplyv osobystisnykh chynnykiv na protses fasylitatyvnoi vzaiemodii [The influence of personal factors on the process of facilitative interaction]. Zbirnyk naukovykh prats «Problemy suchasnoi psykholohii» - Collection of research papers "Problems of modern Psychology», 49, 363-385. Retrieved from https://doi.org/ 10.32626/2227-6246.2020-49.363-385 [in Ukrainian].

Mykhalchuk, Nataliia, \& Kryshevych, Olga (2019). The peculiarities of the perception and understanding of Sonnets written by W. Shakespeare by the students of the Faculty of Foreign Languages. Psykholinhvistika. Psikholingvistika. Psycholinguistics - Psycholinguistics. Psycholinguistics. Psycholinguistics, 26 (1), 265-285. Retrieved from https://doi.org/10.31470/2309-1797-2019-26-1-265-285.

Onufriieva, L.A. (2017). The Psychology of Professional Realization of a Future Specialist's Personality: Theoretical and Methodological Aspect. Rzeszów : BonusLiber. ISBN 978-83-65441-83-6.

\section{Антюхова Наталія, Онуфрієва Ліана. Групова діяльність як психологіч- ний чинник розвитку креативності студентів}

\section{АНОТАЦІЯ}

Мета статmі - дослідити рівень розвитку творчого потенціалу учнів майбутніх учителів іноземних мов, застосувати розроблену нами програму групової діяльності з метою розвитку креативності респондентів, проаналізувати ії ефективність.

Для розв'язання поставлених у роботі завдань використано такі теоретичні методи дослідження: категоріальний, структурно-функціональний, аналіз, систематизація, моделювання, узагальнення, а також експериментальні методи, зокрема, констатувальне дослідження. Використано такі методики: «Мотивація професійної діяльності» К. Замфір у модифікації А. Реана, «Методику визначення спрямованості особистості» (В. Смекало та М. Кучер). Із метою детальнішого опису показника «креативна спрямованість особистості на оволодіння май(C) Antiukhova Nataliia, Onufriieva Liana

DOI (article): https://doi.org/10.32626/2227-6246.2021-53.11-34 http://journals.uran.ua/index.php/2227-6246 
бутньою професією» нами використано прийом ранжування, основною задачею якого було виявити найбільш значущі критерії педагогічної майстерності, які, на думку респондентів, найбільшою мірою впливатимуть на формування творчого потенціалу вчителя іноземної мови.

Результати дослідження. Аналіз отриманих результатів показав, що творчий потенціал особистості виявляється і набувається у процесі такої діяльності, що надає чій діяльності проблемно-творчого, пошукового характеру. Емпіричні дані довели, що досвід творчої діяльності повинен бути базовим елементом, з огляду на який може відбуватися становлення й інших його елементів (знання, вміння, ставлення людини до світу тощо). У цьому випадку навчання та виховання студентів із самого початку навчання у закладах вищої освіти буде спрямовано на розвиток їх особистості, a, отже, й на розвиток їх творчого потенціалу.

Отримані нами емпіричні результати довели, що у процесі профресійної підготовки студентів у закладах вищої освіти в студентів слід актуалізувати психологічні механізми розвитку креативних рис особистості (активності, рефлексивний механізм, механізми становлення самооцінки, саморегуляції). Так, в основі емпіричного і теоретичного (змістового) абстрагування й узагальнення лежать мисленнєві дії, що контролюються завдяки рефлексивним механізмам. Той, хто навчається, у процесі діяльності займає позицію дослідника, твория, здатного до ресрлексивного аналізу власних дій. Оскільки процедура рефлексії тісно пов'язана із самооцінкою та саморегуляцією, то цим процесам у ході навчання, згідно нашої концепції групового навчання, також надається досить суттєве значення.

Висновки. Доведено, що розвивальний характер навчання значною мірою залежить від засобів і методів отримання індивідами теоретичних знань. Зміст розвивального навчання дидактично побудований за логікою теоретичного мислення (провідна роль належить теоретичним змістовим узагальненням, дедукції, змістовій рефллексії тощо).

До прочесуальних характеристик теорії розвивального групового навчання відносяться:

- концепція цілеспрямованої навчальної діяльності, яка відрізняється тим, що спрямована не лише на отримання суб'єктами учіння знань, умінь і навичок, а й на досягнення теоретичного рівня мислення особистості. ї̈ особливостями є: наявність у того, хто навчається, внутрішніх пізнавальних мотивів, що походять від пізнавальних потреб;

(C) Antiukhova Nataliia, Onufriieva Liana DOI (article): https://doi.org/10.32626/2227-6246.2021-53.11-34 
наявність чіткої мети здійснення свідомої самозміни, розуміння й прийняття індивідами всіх без вибору навчальних завдань; зайняття тим, хто навчається, позиції повноцінного суб'єкта діяльності, здатного до самостійного здійснення всіх етапів цієї діяльності: формулювання мети, планування діяльності, реалізації мети й аналізу (оцінки) результатів діяльності; активне засвоєння теоретичних знань, умінь, навичок, способів здійснення розумових дій, цілеспрямоване планування та виконання дій, оволодіння загальними принципами розв'язання проблемних і творчих завдань (учень займає позицію дослідника-твория); рефлексивний характер аналізу власних дій, досвід творчої рефрлексії, що є базовими елементами формування та розвитку особистості;

- проблематизація діяльності - проблемне пояснення педагогом навчального матеріалу, що викликає у тих, хто навчається, неабиякі творчі зусилля креативно презентувати власну думку, формулювати висновки, гіпотези та перевіряти їх у конструктивних діалогах з опонентами;

- використання методу навчальних завдань, який полягає в тому, що розв'язання завдання - не в знаходженні певного висновку, а у відшукуванні загальних способів дії, принципів розв'язання цілого класу аналогічних завдань тощо.

Ключові слова: групова діяльність, розвиток креативності студентів, творчий потенціал студентів, конструктивний діалог з опонентами, формулювання висновків, гіпотез.

\section{Антюхова Наталия, Онуфриева Лиана. Групповая деятельность как психологический фактор развития креативности студентов}

\section{АННОТАЦИЯ}

Цель статьи - исследовать уровень развития творческого потенциала студентов - будущих учителей иностранных языков, применить разработанную нами программу групповой деятельности с целью развития креативности респондентов, проанализировать ее эрфрективность.

Для решения поставленных в работе задач использованы следующие теоретические методы исследования: категориальный, структурно-функциональный, анализ, систематизация, моделирование, обобщение, а также экспериментальные методы, в частности, констатирующий эксперимент. Использованы следующие методики: методика «Мо(c) Antiukhova Nataliia, Onufriieva Liana

DOI (article): https://doi.org/10.32626/2227-6246.2021-53.11-34 http://journals.uran.ua/index.php/2227-6246 
тивация профессиональной деятельности» К. Замфир в модификации А. Реана, "Методика определения направленности личности» (В. Смекало и М. Кучер). С челью более детального описания показателя "креативная направленность личности на овладение будущей профессией» мы использовали прием ранжирования, основной задачей которого было выявить наиболее значимые критерии педагогического мастерства, которые, по мнению респондентов, в наибольшей степени влияют на формирование творческого потенциала учителя иностранного языка.

Результаты исследования. Анализ полученных результатов показал, что творческий потенциал личности проявляется и приобретается в процессе такой деятельности, что придает этой деятельности проблемно-творческий, поисковый характер. Эмпирические данные показали, что опыт творческой деятельности должен быть базовым элементом, учитывая который может происходить становление и других его элементов (знания, умения, отношение человека к миру и др.). В этом случае обучение и воспитание студентов в учреждениях высшего образования направлены на развитие их личности, а, следовательно, и на развитие их творческого потенциала.

Полученные нами эмпирические результаты показали, что в процессе профессиональной подготовки студентов в учреждениях высшего образования у них следует актуализировать психологические механизмы развития креативных черт личности (активности, ресллексивные механизмы психики, механизмы становления самооченки, саморегуляции). Так, в основе эмпирического и теоретического (содержательного) абстрагирования и обобщения находятся мыслительные действия, которые контролируются благодаря рефлексивным механизмам. Учащийся в процессе деятельности занимает позицию исследователя, твориа, способного к рефрлексивному анализу собственных действий. Поскольку процедура редлексии тесно связана с самооценкой и саморегуляцией, то этим процессам в ходе обучения, согласно нашей концепции группового обучения, также уделяется достаточно существенное значение.

Выводы. Доказано, что развивающий характер обучения во многом зависит от средств и методов получения индивидами теоретических знаний. Содержание развивающего обучения дидактически построено по логике теоретического мышления (ведущая роль принадлежит теоретическим процессам содержательного обобщения, дедукции, содержательной рефрлексии и др.).

(C) Antiukhova Nataliia, Onufriieva Liana DOI (article): https://doi.org/10.32626/2227-6246.2021-53.11-34 
DOI: https://doi.org/10.32626/2227-6246.2021-53

2021. випуск 53

К процессуальным характеристикам теории развивающего группового обучения относятся:

- концепция целенаправленной учебной деятельности, которая отличается тем, что направлена не только на получение субъектами обучения знаний, умений и навыков, но и на достижение теоретического уровня мышления личности. Ее особенностями являются: наличие у учащегося внутренних познавательных мотивов, которые во многом исходят от познавательных потребностей; наличие четкой цели осуществления сознательного самоизменения, понимание и принятие индивидами всех без выбора учебных задач; принятие студентами позиции полноценного субъекта деятельности, способного к самостоятельному осуществлению всех этапов этой деятельности: формулировке цели, планированию деятельности, реализации цели и анализу (оценке) результатов деятельности; активное усвоение теоретических знаний, умений, навыков, способов осуществления умственных действий, целенаправленное планирование и выполнение действий, овладение общими принципами решения проблемных и творческих заданий (студент занимает позицию исследователя-творца); рефлексивный характер анализа собственных действий, опыт творческой рефлексии, которые являются базовыми элементами в формировании и развитии личности;

- проблематизация деятельности - проблемное объяснение педагогом учебного материала, что вызывает у студентов незаурядные творческие усилия креативно презентовать собственное мнение, формулировать выводы, гипотезы и проверять их в конструктивных диалогах с оппонентами;

- использование метода учебных задач, который заключается в том, что решение задачи - не в нахождении определенного вывода, а в овладении общими способами осуществления деятельности, в нахождении принципов решения целого класса аналогичных задач.

Ключевые слова: групповая деятельность, развитие креативности студентов, творческий потенциал студентов, конструктивный диалог с оппонентами, формулирование выводов, гипотез.

Original manuscript received April 10, 2021 Revised manuscript accepted May 27, 2021

(c) Antiukhova Nataliia, Onufriieva Liana

DOI (article): https://doi.org/10.32626/2227-6246.2021-53.11-34 